\title{
Introduction to the special section for the 2005 M7.2 Miyagi-oki earthquake
}

\author{
Akira Hasegawa \\ Research Center for Prediction of Earthquakes and Volcanic Eruptions, Graduate School of Science, Tohoku University, Sendai 980-8578, Japan
}

(Received December 11, 2006; Revised December 17, 2006; Accepted December 18, 2006; Online published February 2, 2007)

An $M=7.2$ earthquake occurred on the plate boundary off Miyagi Prefecture, northeastern Japan, at 11:46 a.m. Japanese Standard Time on 16 August 2005, when the number of people returning to their homes after the holidays was at a peak. This earthquake resulted in the Japanese bullet train of Tohoku/Akita/Yamagata/Shinkansen falling out of service for half a day, and it took a whole day for the service to get back to normal. A suspended ceiling also fell at a public facility in Sendai city, and many people were injured. Overall, this earthquake injured 79 people, and caused partial damage to 339 buildings.

Large earthquakes with a magnitude of $\sim 7.5$ have occurred repeatedly at a recurrence interval of ' 37 years along the plate boundary off Miyagi Prefecture. When the $M=7.2$ event occurred in the source area of the anticipated Miyagioki earthquake, more than 27 years had passed since the last event, and the possibility of an earthquake occurrence within the next 10 years exceeded $50 \%$ according to the evaluation report by the Headquarters for Earthquake Research Promotion (2003) of the Japanese government. Among all of the anticipated earthquakes in Japan, this Miyagi-oki earthquake had the highest probability of occurrence.

Although the August 2005 Miyagi-oki earthquake occurred within the source area of the anticipated Miyagioki earthquake, the magnitude was slightly smaller than $\mathrm{M}=7.5$ that had been anticipated. For this reason, the Headquarters for Earthquake Research Promotion predicted that this earthquake is not the anticipated Miyagi-oki earthquake. However, if this 2005 earthquake is not the one anticipated-subsequently denoted here as the "coming" earthquake-when are we to expect the Miyagi-oki earthquake? Moreover, what is happening within the source area of the coming Miyagi-oki earthquake at this moment? It is critical for us to provide answers to those questions in order to get a clear picture of the coming Miyagi-oki earthquake.

Dense nationwide seismic and GPS networks, which were recently constructed as the "Kiban" networks [in Japanese, this means the basic observation network (Okada et al., 2004; Sagiya, 2004)], were successful in recording the mainshock rupture, aftershock activity and post-

Copy right(c) The Society of Geomagnetism and Earth, Planetary and Space Sciences (SGEPSS); The Seismological Society of Japan; The Volcanological Society of Japan; The Geodetic Society of Japan; The Japanese Society for Planetary Sciences; TERRAPUB. seismic deformation in detail. In addition to these permanent observation networks on land, a temporary OBS network has been deployed right above the source area (Hino et al., 2006), which enabled the mainshock and aftershock hypocenters to be precisely located. Many studies have been carried out based on data obtained by these observation networks. For example, in order to understand how this earthquake is related to the coming Miyagi-oki earthquake, comparative studies between this earthquake and the past large earthquakes off Miyagi Prefecture have been vigorously carried out.

A comparison of the aftershock distribution of the 2005 Miyagi-oki earthquake with that of the previous $1978 \mathrm{M}=7.4$ Miyagi-oki earthquake shows that the aftershock area of the 2005 event partly overlaps the southern/southeastern part of that of the 1978 event (Okada et al., 2005). Waveform inversions of the two events show that the coseismic slip area of the 2005 event also partly overlaps the southeastern part of that of the 1978 event (Yaginuma et al., 2006; Yamanaka and Kikuchi, 2004; Wu and Koketsu, 2005). These observations indicate that only a portion of the rupture area of the previous 1978 event ruptured during this 2005 earthquake.

The present special section is a collection of papers on the $2005 \mathrm{M}=7.2$ Miyagi-oki earthquake. I hope that these studies will contribute toward our developing a clear picture of the impending Miyagi-oki earthquake and to a deepening of our understanding of the mechanism of earthquake generation in general.

\section{References}

Hino, R., Y. Yamamoto, A. Kuwano, M. Nishino, T. Kanazawa, T. Yamada, K. Nakahigashi, K. Mochizuki, M. Shinohara, K. Minato, G. Aoki, N. Okawara, M. Tanaka, M. Abe, E. Araki, S. Kodaira, G. Fujie, and Y. Kaneda, Hypocenter distribution of the main- and aftershocks of the 2005 Off Miyagi Prefecture Earthquake located by ocean bottom seismographic data, Earth Planets Space, 58, this issue, 1543-1547, 2006.

Okada, T., T. Yaginuma, N. Umino, T. Kono, T. Matsuzawa, S. Kita, and A. Hasegawa, The 2005 M 7.2 Miyagi-oki Earthquake, NE Japan: Possible Re-Rupturing of one of asperities that caused the previous M7.4 Earthquake, Geophys. Res. Lett., 32, L24302, doi:10.1029/2005GL024613, 2005.

Okada, Y., K. Kasahara, S. Hori, K. Obara, S. Sekiguchi, H. Fujiwara, and A. Yamamoto, Recent progress of seismic observation networks in Japan-Hi-net, F-net, K-NET and KiK-net, Earth Planets Space, 56, 15-28, 2004.

Sagiya, T., A decade of GEONET: 1994-2003-The continuous GPS observation in Japan and its impact on earthquake studies, Earth Planets 
Space, 56, xxix-xli, 2004.

The Headquaters for Earthquake Research Promotion, MEXT, Japan, Long-term evaluation of the Miyagi-Oki earthquakes, http://www. jishin.go.jp/main/index.html, 2003 (in Japanese).

Wu, C. and K. Koketsu, Source processes of the 2005 and 1978 Miyagiken Oki earthquakes inverted from strong motion records, Prog. Abstr. Seismol. Soc. Japan, 2005 Fall meeting PM20, 2005.

Yaginuma, T., T. Okada, Y. Yagi, T. Matsuzawa, N. Umino, and A. Hasegawa, Coseismic slip distribution of the 2005 off Miyagi earth- quake (M7.2) estimated by inversion of teleseismic and regional seismograms, Earth Planets Space, 58, this issue, 1549-1554, 2006.

Yamanaka, Y. and M. Kikuchi, Asperity map along the subduction zone in northeastern Japan inferred from regional seismic data, J. Geophys Res, 109, 2003JB002683, 2004.

A. Hasegawa (e-mail: hasegawa@aob.geophys.tohoku.ac.jp) 